\title{
Warren Mundine in Black and White
}

MURRAY GOOT AND TIM ROWSE'

Indigenous autobiography is a flourishing genre, but few of their authors are or have been political figures. ${ }^{2}$ Warren Mundine-at various times a shire councillor, president of the Australian Labor Party (ALP) and unsuccessful Liberal Party candidate-is the most seasoned Indigenous political figure yet to attempt an autobiography. Warren Mundine in Black + White: Race, Politics and Changing Australia, Mundine's memoir of his family, marriages and political career, is also his incomplete political manifesto. ${ }^{3}$ Mundine is not looking back in tranquillity; he is in the midst of a political career that could yet see him in the Australian Parliament. His book is written with the confidence of someone who is frequently before the public, a respected and at times iconoclastic commentator on public affairs.

Incomplete manifesto? We say 'manifesto' because his story not only offers his views about how Australia ought to approach Indigenous policy issues, it also seeks to justify them by referring to his family history. (In this he is very like Stan Grant.) We say 'incomplete', because Mundine says hardly anything about the positions that he has taken on one of the most important 'Indigenous issues' of the recent past: whether and how to recognise Aboriginal and Torres Strait Islander peoples in Australia's Constitution. We will argue here that Mundine has emerged as an important figure in what now appears to be the failure of the campaign to recognise Indigenous Australians in the Constitution. You would not know from his book that from 2010 to the end of 2016, there were roughly 40 items in the Australian and a clutch of the Fairfax (now Nine) newspapers that referred to Mundine's sceptical views on constitutional recognition. We will describe the most important of his interventions in more detail later, but the fact for the reader to note immediately is that in these press reports, Mundine is represented as dismissive of positions argued by many Indigenous leaders. Even before the Julia Gillard-appointed Expert Panel had published its recommended changes to the Constitution (in January 2012), he had publicly rejected what proved to be the panel's most contentious proposal: that

\footnotetext{
1 The authors wish to thank the anonymous referees and the editors of this article.

2 For a brief survey of some of the exceptions, see Tim Rowse, 'Aboriginality and Impersonality: Three Australian Indigenous Administrative Memoirs', in Australian Political Lives: Chronicling Political Careers and Administrative Histories, ed. Tracey Arklay, John Nethercote and John Wanna (Canberra: ANU E Press, 2006), 65-71, doi.org/ 10.22459/APL.10.2006.10.

3 Nyunggai Warren Mundine, Warren Mundine in Black + White: Race, Politics and Changing Australia, 2nd ed. (Neutral Bay, NSW: Pantera Press, 2017/18).
} 
the Constitution be amended to forbid laws and policies that discriminate on the basis of 'race, colour or ethnic or national origin' except where such discrimination is 'for the purpose of overcoming disadvantage, ameliorating the effects of past discrimination, or protecting the cultures, languages or heritage of any group'. ${ }^{4}$

Mundine's early critique of what some had begun to call Indigenous constitutional 'overreach' made him a 'go-to' commentator for journalists writing in the Australian, the main platform for debate about constitutional recognition since 2011; he was a reliable source for News Corps media, more generally, keen to publish Indigenous views sceptical of 'symbolic' change and in favour of 'practical' change-for example, on the issue of Australia Day. ${ }^{5}$ So respected by recognition-sceptics had Mundine become by 2015, especially on the Right, that when he turned his fire on another possible reform of the Constitution—dedicated 'Indigenous' seats in the Australian Parliament-Greg Sheridan remarked that 'If you can't sell this proposal to Warren Mundine, you can't sell it to middle Australia'. ${ }^{6}$ A few weeks earlier, Marcia Langton had positioned Mundine as representing a 'minority' of Indigenous opinion; she urged readers not to expect Aboriginal 'consensus'.?

Mundine's memoir mentions neither of these attempts to position him; he chooses not to narrate his many interventions (2011-16) in the debate on constitutional recognition. This is not because he is embarrassed about his heterodox Indigeneity or his 'middle Australia'-ness. On the contrary, he uses the approving phrase 'regular people' (p. 191) to refer to those Australians with whom he imagines himself aligned, and he celebrates his 'radical' independence of mind as a loathed scourge of 'the Aboriginal establishment' (p. 230); for some, he is part of an Aboriginal 'counterestablishment', and part of a minority within that. ${ }^{8}$ His book's almost total neglect of the constitutional recognition debate can be explained as a consequence of his view-shared by a number of other Indigenous figures, including those not on the Right ${ }^{\text {' }}$ - that the Constitution is not relevant to Indigenous advancement. The Constitution sets out 'the structures and processes of government, and the division of powers between the Commonwealth and the states. It doesn't and shouldn't, mandate how that power is exercised' (p. 453). It was consistent with this position that his immediate response to the Uluru Statement from the Heart was to dismiss

\footnotetext{
4 Expert Panel on Constitutional Recognition of Indigenous Australians, Recognising Aboriginal and Torres Strait Islander Peoples in the Constitution: Report of the Expert Panel, Patrick Dodson and Mark Leibler [Co-Chairs], (Canberra: Commonwealth of Australia, 2012), xviii.

5 Noted in Chris Mitchell, 'Media and Politicians Misread the Public Mood by Relying on Social Media', Australian, 1 February 2021.

6 Greg Sheridan, 'Mundine’s Persuasive Blow Knocks Out Pearson's Case', Australian, 11 June 2015.

7 Marcia Langton, 'Pearson's Proposals Deserve Recognition', Australian, 18-19 April 2015.

8 Geoff Robinson, Being Left-Wing in Australia: Identity, Culture and Politics after Socialism (North Melbourne: Australian Scholarly Publishing, 2019), 179, 284-85.

9 See, for example, Michael Mansell, 'Is the Constitution a Better Tool than Simple Legislation to Advance the Cause of Aboriginal peoples?', in It's Our Country: Indigenous Arguments for Meaningful Constitutional Recognition and Reform, ed. Megan Davis and Marcia Langton (Carlton, Vic.: Melbourne University Press, 2016).
} 
its call for entrenching a Voice to Parliament in the Constitution. ${ }^{10}$ However, as we will show, Mundine has not been able fully to detach himself from the ongoing debate about constitutional recognition, and he now occupies an important position within it.

\section{The Mundine line: Don't rely on government}

Mundine was born at the Grafton Hospital in 1956, into a large family (Bundjalung father, Gumbaynggirr mother) that had never lived on a mission or reserve. His ancestors had survived invasion under the informal protection of pastoralist patrons, Edward and Frederick Ogilvie, who occupied land on the Clarence River in the 1840s, calling it Yulgilbar Station. Local Bundjalung made 'a truce of sorts' that included the Ogilvies setting aside some land for the families of Aboriginal workers and Edward's attendance at ceremonies. The Ogilvies sold Yulgilbar to the Hordern family in 1926, and the Horderns demarcated land for Aboriginal families that came to be known as Baryulgil; his father, Roy, was born there between 1916 and 1919, into a family that led the Baryulgil community.

Under such a privatised version of 'protection', the state protection laws applied to the people of Baryulgil only to a limited extent. Mundine tells a story of the Hordern family patrons keeping the police from harassing his grandfather Harry (p. 33). According to Mundine, neither government nor mission authorities rationed the Baryulgil mob; they found their own food and water, and built their own shelters. Mundine presents himself as deeply formed by this tradition of hard-working selfsufficiency, the ability to live at least partly off the country. 'One thing my family modelled for me was that you don't wait for government or anyone else to give you self-determination. You take it' (p. 31). Roy Mundine was able to attend the Baryulgil public school, and as an adult was an avid reader. Mundine recalls with gratitude that he grew up 'in a culture of working, where work was seen as a virtue, as the most important thing you could do' (p. 504). The Mundines were proud but also watchful of their place in a society that, under Australia's post-World War II 'assimilation' policy, continued to be racially stratified.

Mundine's parents, Roy and Dolly, met in Grafton where both had found work; after the birth of their first child, they began to live in South Grafton, first renting and then buying a home in 1947. As a literate, employed 'half caste', Roy qualified to be an 'exempt Aborigine' sometime in the 1950s. Because Australian mores included ways to remind 'upstanding' (p. 74), voting, home-owning and upwardly mobile Aboriginal people that they were, nonetheless, 'still Abos', 'us kids grew up

10 Warren Mundine, 'We Don't Need an Indigenous Treaty: We Need Many', Australian Financial Review, 31 May 2017. 
learning to hang back in shops and not cause trouble or draw attention to ourselves' (p. 73). The Mundines 'experienced a hybrid life between the full restrictions of the law and the freedoms everyone else had' (p. 7). After paying off their house in 1962, the family moved to Redfern in 1963 and then to Auburn, seeking better education and opportunities, and finding a less abusive 'protection regime' (p. 83). Roy was a staunch member of the Australian Workers' Union, and so Mundine grew up in a Labor household. 'Labor values were very much about the dignity and value of work and its contribution to the family and the community' (p. 505).

Mundine's wider political awareness was stimulated by observing African-American resurgence in the 1960s and, by the early 1970s, still in high school (Marist Brothers), he had a 'passion for politics' (p. 98). When he enrolled for an Associate Diploma in Community Development at the South Australian Institute of Technology in 1982, his reading included Milton Friedman (1912-2006) the Nobel Prize-winning economist who gave intellectual authority to fiscal and monetary policies that undermined many of the public policy achievements of postwar social democratic liberalism. Mundine remained, at that time, 'more of a Keynesian' (p. 121). More formative was his participation in demonstrations in Brisbane (during the 1982 Commonwealth Games) against Queensland's continuing 'protection' regime. His immersion in Aboriginal movement politics continued as he attended talks at Tranby College in Sydney. There he met the Kanak leader Jean-Marie Tjibaou to whom he attributes the argument that colonised peoples must modernise to survive. Mundine sees precedent for that view in the 1938 statement 'Aborigines claim citizen rights!' whose Koori authors had spurned programs that professed to conserve native culture, 'like koala bears' (p. 129).

A vehicle of Koori modernisation soon appeared: the New South Wales (NSW) Land Rights Act 1983. Mundine served for a year on the Interim NSW Aboriginal Land Council. It is important to remember how ambivalently NSW Aboriginal people greeted this statute. The Act, which handed over the remaining 6,000 acres of reserve land to the Aboriginal communities that resided there, was complemented by another that retrospectively validated the theft of 25,000 acres of 'old reserve' lands created since 1911. ${ }^{11}$ In its concession of 'land rights', the Wran Government confirmed a longstanding and deeply felt Koori distrust of the state government. Nonetheless, this was the 'land rights' that they had to work with. In 1985, Mundine and his new wife Lynette Riley moved to Armidale where Mundine became coordinator of the Northern Tablelands Regional Aboriginal Land Council; that work formed what became his abiding view that 'commerce, private ownership, jobs and education' were essential to Aboriginal advancement. He observed that other Aboriginal people, no less committed than he to the principle of land rights, did not

11 Heather Goodall, Invasion to Embassy: Land in Aboriginal Politics in New South Wales, 1770-1972 (St Leonards, NSW: Allen \& Unwin, 1996), 357. 
necessarily agree with his belief that land was a platform for economic development. They seemed to him to lack the confidence to start enterprises and the know-how to make them last. Some local Aboriginal Land Council functionaries were not literate or numerate and had not grasped elementary principles of governance. To these problems the 'activist clique' in the NSW land rights movement had no answers, he laments. They blamed 'the past' and looked to government for assistance (p. 142). Thus, his participation in statutory 'land rights' administration confirmed Mundine's long-held tendency to see government as either irrelevant or as part of the problem: looking to government was a self-defeating habit of Aboriginal politics.

\section{A Labor man?}

Nonetheless, Mundine remained a Labor man. What he saw as the economic liberalism of the Hawke and Keating governments, including the legislation of 'native title' as a property right in 1993, sustained his faith. However, Mundine goes to some trouble to prepare us for his eventual break with the Party. Reading Friedman again, he realised he 'wasn't a socialist after all' (p. 144). What had changed in his life is not clear. Whether it was Friedman's views on monetary policy (influential since the mid-1970s) or on income redistribution (something elements of the Labor parliamentary Left, including Lindsay Tanner, finance minister under Gillard and Kevin Rudd, embraced later), he doesn't say. 'For the time being,' Keating remarked of his monetary policy, at the time of Friedman's visit to Australia in 1975, 'there's too much resistance within the Labor caucus ... for Friedman's ideas to be embraced by the [Labor] government' . ${ }^{2}$ Under Mundine's 'heroes', Hawke and Keating, whose economic policies he admired (p. 143), many said Labor was no longer socialist - if it ever had been. So, the break with Labor was still some time off, driven less perhaps by ideology than by Mundine's lack of advancement.

In his first bid for political office, he stood as an Independent in the 1991 Armidale City Council election, without success. In late 1992, he and Lynette moved to Dubbo, for Lynette's career. Mundine found no job but there were many opportunities for activism in football administration and community arts. Such work aroused his interest in standing for the Dubbo City Council. Presenting himself again as an Independent in 1995, he succeeded. Having been helped by Dubbo's Daily Liberal, it is not surprising that the Liberal Party then offered him membership. But this did not align 'with who I was and where I'd come from' (p. 168), so he became a member of the ALP, deciding to join the Right faction rather than the Left because, he recalls with calculated bathos, the Left faction dinner would have cost him $\$ 25$, while the Right's dinner was without charge (pp. 168-69). 
Mundine began to involve himself in the Labor Party. At the 1999 New South Wales state election, he stood for the ALP in Dubbo. Described by Bradley Bowden as Labor's 'high profile candidate' and 'a leader of the electorate's large Aboriginal community', Mundine received just 20 per cent of the vote. ${ }^{13}$ Although he 'did well ... in the "redneck towns", he says, and reports that his first preference vote represented a 'huge swing' to Labor (p. 177), Labor's first preference vote fell by a third; in fact, the 'huge swing' was only evident in the rise from 32 to 39.5 per cent on the two-candidate preferred. ${ }^{14}$ Two years later, he secured the third position on Labor's Senate ticket for New South Wales-a position, he says, Labor expected to win. Labor could not have won it. ${ }^{15}$ Had the number three spot in 2001 been winnable, Mundine might not have been the party's choice. The award of a Centenary Medal may have brought some consolation.

While he was 'gutted' not to have been elected, the contest built his self-confidence. 'If you're willing to have a go, possibilities open up' (p. 186). Convinced that he was a 'political operative' in his 'own right' (p. 185), he stood for deputy mayor in Dubbo's City Council elections in 2002 and was elected; he held the position until 2004. In 2001, 2002 and 2003, he was named Councillor of the Year by the NSW Local Government Aboriginal Network, and from 2002 to 2004 he served on the executive committee of the NSW Local Government Association. With Labor in government, under Bob Carr, Mundine served as a commissioner of the NSW Local Government Grants Commission (2002-04), a member of the NSW AttorneyGeneral's Juvenile Crime Prevention Committee (2002-04), and as a member of the Macquarie Area Health Board (2002-06). ${ }^{16}$

In 2004, Mundine challenged the sitting Labor member, Julia Irwin, for Labor preselection in the federal seat of Fowler. The challenge was unsuccessful. Having shown scant knowledge of the party's preselection procedures, and relying on 'senior factional leaders' (p. 246) rather than the local branches, Mundine covered for Head Office's failure to deliver for him by declaring his support for affirmative action (pp. 244-48). ${ }^{17}$ In 2012, in a final attempt to represent Labor, Mundine threw his 'hat in the ring' to replace former NSW party secretary Mark Arbib in the Senate, only to feel 'shafted' when the 'Labor back room' backed Carr (pp. 335-36). The Right, 'structured to seek and receive reports on emerging possibilities', says Cavalier, had 'mark[ed] his card' as "'encourage in pursuit of prizes unwinnable, lavish flattery recommended, useful for shop window"'.18

13 Bradley Bowden, 'The Nationals and Rural Politics', in From Carr to Keneally: Labor in Office in NSW 19952011, ed. David Clune and Rodney Smith (Sydney: Allen \& Unwin, 2012), 34.

14 Our thanks to Antony Green for the figures.

15 Rodney Cavalier, 'Warren Mundine Comes Home', Southern Highlands Newsletter, no. 231, vol. 2 (2019), 53;

also, Malcolm Mackerras, pers. comm., 5 November 2020.

16 Who's Who in Australia 2020 (Southbank, Vic.: AAP Directories, 2020), 1209.

17 Cavalier, 'Warren Mundine Comes Home', 55. For a more sympathetic account, see Stephen Fitzpatrick, 'A Survivor Pulls No Punches', Weekend Australian, 9-10 December 2017.

18 Cavalier, 'Warren Mundine Comes Home', 52. 
One 'shop window' was the party presidency. In 2003, eight years after joining the Labor Party, Mundine headed the Right's ticket for the party presidency, 'deeply uncomfortable' though he was 'with some hard Right policies' ${ }^{19}$ After coming third with 12.4 per cent of the vote, in the first postal ballot of party members, Mundine was elected (along with Carmen Lawrence who came first and Barry Jones who came second), ensuring that it would be his turn to serve as junior vice-president in 2004, senior vice-president in 2005 and as president in 2006. All three worked well together, says Jones ${ }^{20}$ — their views on refugees no doubt at odds with those of Mark Latham, elected member for Werriwa in 1994 and Labor leader from December 2003 to October 2004. ${ }^{21}$ Mundine told members unhappy with the party to 'stop whingeing, get in there and fix it'. ${ }^{22}$

In his memoir, he highlights one episode of his presidency. He publicly confronted Queensland Labor Premier Peter Beattie to demand that his government cease appeasing the Police Union and prosecute Sergeant Chris Hurley for killing Cameron (Mulrungi) Doomadgee inside Palm Island police station. In Beattie's memoir, Making a Difference: Reflections on Life, Leadership and Politics (2005), the killing does not rate a mention. ${ }^{23}$

The succession of ALP offices afforded Mundine a good position to observe Latham. Although he found Latham's leadership appalling - was he aware that, in 2004, Latham championed a community-based model to replace the Aboriginal and Torres Strait Islander Commission (ATSIC), and resisted exhortations from Labor's head office in New South Wales to 'bash the blacks'?24 - his view of the Labor Party would evolve along lines similar to Latham's. Like the former leader, Mundine would form the view that Labor has lost touch with prospering workingclass people (pp. 350-51), and that Labor loses the 'country and suburban' vote to the extent that it panders to inner-city 'bleeding heart types' (p. 193), the people 'sitting in cafes in the inner city' who do not like mining (p. 353)_and, though he does not say, who do like refugees. If the difficulty of bridging those two Labor constituencies is now the ALP's ongoing torment, it was one reason for Mundine to attenuate his Labor affiliation and, in 2012, to let his membership lapse; no more

19 Mundine's reservations are noted in Barry Jones, A Thinking Reed (Crows Nest, NSW: Allen \& Unwin, 2006), 470-71.

20 Barry Jones, 'Where Are We Coming From? Where Are We Going?', in Coming to the Party: Where to Next for Labor?, ed. Barry Jones (Carlton, Vic.: Melbourne University Press, 2006).

21 Latham would have 'been comfortable' voting for John Howard's Tampa legislation; Mark Latham, 'Left Wrongness', Australian Financial Review, 10 August 2013, reprinted in Latham at Large (Carlton, Vic.: Melbourne University Press, 2015), 126.

22 Quoted in John Langmore, 'Howard's End', in Jones, Coming to the Party, 203.

23 The killing is examined in Chloe Hooper, The Tall Man: Death and Life on Palm Island (Camberwell, Vic.: Penguin, 2008).

24 Mark Latham, The Latham Diaries (Carlton, Vic.: Melbourne University Press, 2005), 279, 369. 
'get[ting] in there and fix[ing] it'. 'Labor didn't know its heartland any more', he had concluded (p. 354). So mindful of its membership was the party, that no one contacted him to ask why he was not renewing (p. 350).

But Mundine gave an interview to the Australian —an effort to inform the world, 'especially the Liberal Party', that he was no longer an ALP member. ${ }^{25}$ In February, during a meeting with Tony Abbott (leader of the Opposition) and George Brandis (shadow attorney-general) to discuss constitutional change, Abbott had joked with Mundine that he was 'on the wrong team'. Though still a Labor man, 'Mundine seemed pleased'. ${ }^{26}$ A friendship between the two men had 'blossomed' in 2008, after Mundine had been asked by Jenny Macklin, minister for Indigenous affairs, to negotiate with Abbott, her Shadow, 'over the reintroduction of the Racial Discrimination Act in the Northern Territory. ${ }^{27}$

Mundine's distancing from the ALP began, even as he rose within it, with two steps. He took the first by agreeing to play a public role in the Howard Government's reconstruction of Indigenous Affairs. In November 2002, the government initiated a review of ATSIC. After receiving the report in November 2003, it announced in April 2004 that it would abolish ATSIC and replace it with a National Indigenous Council (NIC), chaired by Sue Gordon, whose members would be chosen not as representatives but for their policy experience. Mundine-now a vice-president of the ALP-agreed to be a council member and thus a policy adviser to a nonLabor government; he would later be one of the Indigenous voices in support of the Coalition's Northern Territory intervention. ${ }^{28}$ Mundine writes that the Labor colleagues whom he consulted about this decision, including Latham, urged him to accept Howard's invitation (p. 280). The NIC held its first meeting in December 2004.

The other step Mundine took was to issue a media release, shortly after his NIC appointment was announced, in which he questioned the value of what he labelled 'communal' land tenure and advocated 'home ownership, economic development and profit-making businesses' (p. 222). ${ }^{29} \mathrm{He}$ took this step as CEO of NTSCorpthe company providing native title services for Aboriginal traditional owners in New South Wales and the Australian Capital Territory. For Mundine, the primary significance of land to Aboriginal people is that it is a strategic economic asset and

\footnotetext{
25 Cavalier, 'Warren Mundine Comes Home', 56.

26 Shireen Morris, Radical Heart: Three Stories Make Us One (Carlton, Vic.: Melbourne University Press, 2018), 65.

27 Natasha Robinson, 'Warren Mundine Ready to Assume Position of Power under Tony Abbott', Australian, 18 May 2013.

28 Sarah Maddison, Black Politics: Inside the Complexity of Aboriginal Political Culture (Crows Nest, NSW: Allen \& Unwin, 2009), 17; see also Kerry McCallum and Lisa Waller, The Dynamics of News and Indigenous Policy in Australia (Bristol: Intellect, 2017), 157.

29 See also Mundine's remarks in January 2005 on ABC Radio's Counterpoint, quoted in David Ritter, Contesting Native Title: From Controversy to Consensus in the Struggle over Indigenous Land Rights (Crows Nest, NSW: Allen \& Unwin, 2009), 42-43.
} 
a basis for families to own homes; the values Mundine took from his home, says Rodney Cavalier, minister for education in the Wran and Unsworth governments, were 'four-square Liberal Party'. ${ }^{30}$ Well before June 2005, when he had restated his position, in 'one of the most important speeches' in his life (p. 226), to a hostile audience at the National Native Title Conference, Mundine tells us that he had become 'one of the most loathed people in Indigenous Affairs' (p. 222). Almost immediately, he was awarded the Bennelong Medal for being 'a brave advocate for change', including change to 'the way community owned land is controlled'. ${ }^{31}$

While the Labor Party in 2004 was quick to say that it was not reconsidering its support for 'communal land tenure', it allowed Mundine to serve out his term as senior vice-president and then president. That the Party had grounds by then for judging him politically unsound does not occur to him. More than he cares to consider, Mundine talked himself out of the ALP's favour. The year after letting his membership lapse, he married Elizabeth Henderson, daughter of two of the stalwarts of conservative politics in Australia, the Sydney Institute's Gerard Henderson and Anne Henderson; Warren had met Elizabeth, in 2009, at an institute dinner (p. 331). Free of Labor, his ties with the conservative side of politics grew. In 2012, he became an Alan McGregor Fellow at the Centre for Independent Studies.

Coalition Government interest in Mundine continued. Shortly after coming to office, in 2013, Abbott appointed him to chair the government's Indigenous Advisory Council; in 2016, Linda Burney, the Labor member for Barton, attacked Mundine for:

oversee[ing] ... the demolition of child and family services across Australia, the demolition of half a billion dollars out of the Indigenous affairs budget, the demolition of Aboriginal legal centres that support women to pursue issues of domestic violence, and the demolition of most of the advocacy services in Aboriginal affairs, including the withdrawal of federal funding from a number of Aboriginal programs that specifically work at the community levels dealing with family violence. ${ }^{32}$

In 2017, Malcolm Turnbull, who had replaced Abbott in September 2015, reconstructed the council, which had not met since May 2015, and Mundine was dumped. Mundine, who had gone public with comments critical of Turnbull's decision to call a royal commission into the Don Dale Detention Centre-the more

30 Cavalier, 'Warren Mundine Comes Home', 52.

31 'Bennelong Society', Wikipedia, en.wikipedia.org/wiki/Bennelong_Society. For his subsequent emphasis on leasing rather than selling land, see Maddison, Black Politics, 92.

32 Allan Clarke, 'Linda Burney Slams Warren Mundine Over Claims the Aboriginal Community Ignores Domestic Violence', Buzzfeed, 5 October 2016, www.buzzfeed.com/allanclarke/linda-burney-slams-warren-mundine. 
important problem, he implied, being the violence Indigenous women suffered from their Indigenous partners ${ }^{33}$ - was quoted, a few months later, as saying that Turnbull had 'no interest in Indigenous affairs.' ${ }^{34}$

Under the Indigenous Advancement Strategy, established by Abbott, under which all Aboriginal organisations, regardless of their size, had to compete for funding, the Turnbull Government, in June 2017, had given Mundine's company Nyungga Black Group \$220,000 to provide advice on remote economic development, and $\$ 110,000$ to fund Mundine Means Business on Sky News. ${ }^{35}$ In 2018, the Turnbull Government gave another $\$ 220,000$ to help fund a second series of this showboth grants awarded on the basis of a direct approach rather than a tendering process, Buzzfeed reported. It was very likely, the relevant minister conceded, that no other Indigenous business person had been 'offered the opportunity to receive government funding for a television program. ${ }^{36}$ Mundine has been Chair of the Australian Indigenous Chamber of Commerce since 2008, Elizabeth also serving in recent years as a Director and Company Secretary. ${ }^{37}$

In January 2019, Mundine won Liberal endorsement for the marginal, 'mustwin' seat of Gilmore, the New South Wales executive of the Party intervening on behalf of the Prime Minister to overturn the local party's choice, Grant Schultz. ${ }^{38}$ Polling in Gilmore, conducted in November, 'came back really good' for Mundine, according to a senior Liberal source. 'While he's an outsider to the Liberal Party, that's his strength,' the source explained..$^{39}$ Once endorsed, Mundine stood down as chair of RISE Ventures, a company with government contracts to provide Indigenous employment services, and took steps (including hiring a QC) to divest himself of all other business interests. ${ }^{40}$ 'Make no mistake,' wrote Anna Caldwell,

33 Nyunggai Warren Mundine, 'Indigenous People Must Find a Voice to Condemn Domestic Violence', Australian, 3 October 2016.

34 Rashida Yosufzai, 'I Don't Know What He Stands For: Warren Mundine Attacks Malcolm Turnbull', SBS News, 31 October 2017, www.sbs.com.au/news/i-don-t-know-what-he-stands-for-warren-mundine-attacksmalcolm-turnbull.

35 Josh Taylor, 'The Government Gave a Grant to Warren Mundine for His Sky News Show', Buzzfeed, 25 January 2019, www.buzzfeed.com/joshtaylor/warren-mundine-sky-news-show-grant.

36 Hannah Ryan, 'The Government Spent \$330,000 Funding a Sky News Program’, Buzzfeed, 25 January 2019, www.buzzfeed.com/hannahryan/warren-mundine-sky-news-funding-grant; Josh Taylor, 'Warren Mundine Approved for Sky News TV Grant before Applying', Guardian (Australian ed.), 28 June 2019, www.theguardian. com/australia-news/2019/jun/28/warren-mundine-approved-for-sky-news-government-grant-before-applying; Michael Koziol, 'Mundine Wildcard Is Worth a Gamble, Say Libs', Sydney Morning Herald, 26-27 January 2019.

37 'Our People', Australian Indigenous Chamber of Commerce, www.indigenouschamber.org.au/our-people/.

38 Shane Wright, 'PM Rolls the Mundine Dice', Sydney Morning Herald, 25 January 2019; Anika Gauja and Marija Taflaga, 'Candidates and Pre-selection', in Morrison's Miracle: The 2019 Federal Election, ed. Anika Gauja, Marian Sawer and Marian Simms (Canberra: ANU Press, 2020), 78-79, doi.org/10.22459/MM.2020.04.

39 Michael Koziol, 'Liberal Fury as Morrison Intervenes in Crucial Seat', Sydney Morning Herald, 23 January 2019; Michael Koziol, Kylar Loussikian and Bevan Shields, 'Three-Way Fight for Gilmore Set to Grab Focus', Sydney Morning Herald, 19-20 January 2019; Tom McIlroy, 'Former ALP Boss to Run as a Liberal', Australian Financial Review, 23 January 2019.

40 Ryan, 'Government Spent \$330,000 Funding a Sky News Program'. 
state political reporter for Sydney's Daily Telegraph, 'Mundine has the potential to be a devastatingly effective warrior in the government's battle to stop Shorten becoming prime minister'. ${ }^{41}$ Mundine was now a columnist for the Telegraph — with pieces attacking socialism and defending coal. ${ }^{42}$ To Liberals 'whingeing' over Scott Morrison's 'installation' of Mundine, Caldwell counselled that Mundine had 'the potential to be one of the nation's great politicians s. ${ }^{43}$ Having previously considered entering the New South Wales Parliament as a Liberal Democrat, ${ }^{44}$ Mundine now saw the Liberals 'as the true party of the working class'. ${ }^{45}$ As well as knowing 'how to take on the headkickers of the left', Mundine believed he could 'bring the indigenous vote of the South Coast with him to the coalition'. ${ }^{46}$ Mundine not only failed to win Gilmore, a Liberal-held seat, he suffered a 16.1 percentage point swing on first preferences - evidence perhaps of the inability of polling to measure in advance the transaction costs of a 'captain's pick'.

Fortunately, for Mundine, there was a safety net to catch him. In late 2020, he became the chair of Liberty Works and of CPAC (the Conservative Political Action Conference). ${ }^{47} \mathrm{He}$ was also appointed to the Board of SBS (Special Broadcasting Service), the government overriding the advice of its independent nominations panel. ${ }^{48}$ Commentator Peter Brent suggested, implausibly, that he had been picked not 'to be elected' as the member for Gilmore, but rather 'to flesh out the wider Liberal image of the campaign: a successful, conservative businessman with a Labor background ... happy to explain ... why Bill Shorten shouldn't be allowed anywhere near the Lodge'. ${ }^{49}$ With the Liberals, Mundine has found the kind of home that Labor never gave him.

\section{What is Aboriginal development?}

Mundine professes to admire societies that have rapidly renovated themselves in response to colonisation, and he devotes several pages to east Asian autocracies, China, Japan and South Korea (pp. 259-61, 267-70). In Japan's Meiji Restoration

\footnotetext{
41 Anna Caldwell, 'Civil War in Gilmore’, Daily Telegraph, 25 January 2019.

42 Warren Mundine, 'Don't Fall for Socialism', Daily Telegraph, 31 January 2019; 'Warren Mundine: The Greens' Renewable Energy Agenda Is Fiction', Daily Telegraph, 21 February 2019.

43 Caldwell, 'Civil War in Gilmore'.

44 Taylor, 'Government Gave a \$220,000 Grant to Warren Mundine for His Sky News Show'.

45 Anna Caldwell, 'Former ALP President Warren Mundine Says Liberals the True Party of the Working Class',

Daily Telegraph, 23 January 2019.

46 Caldwell, 'Civil War in Gilmore'.

47 'Warren Mundine', Liberty Works, www.libertyworks.org.au/people/warren_mundine.

48 Amanda Meade, 'Warren Mundine Was Not Recommended for the SBS Board but the Coalition Chose Him Anyway', Guardian (Australian edition), 4 November 2020, www.theguardian.com/australia-news/2020/nov/04/ warren-mundine-was-not-recommended-for-the-sbs-board-but-the-coalition-chose-him-anyway.

49 Peter Brent, 'For Whom a Bellwether Tolls', Inside Story, 25 January 2019, insidestory.org.au/for-whom-abellwether-tolls/.
} 
from 1867, an elite coalition of daimyo, imperial princes, court nobles and samurai formed a government that pre-empted Western powers' occupation by imposing new institutions and technologies modelled by the nation-states of Europe and the North Atlantic. This made Japan strong enough to colonise Formosa (1895), defeat Russia (1905), to annex Korea (1910), to take over Germany's spheres of influence in China (1919), followed by invasion of northern China (1931-35). After the Japanese empire was defeated in 1945, South Korea's economic development program included enduring many years of authoritarian rule under General Park Chung Hee (1961-79). China emerged from Japan's rule under Communist Party direction by 1949, but it abandoned a socialist program after 40 years to pursue an authoritarian version of state capitalism whose poverty-relieving results Mundine admires. At no point in his discussion of these East Asian transitions from colonisation to mass prosperity does Mundine consider the cost to 'Liberal values supporting individual rights' (p. 229) that these regimes were willing to pay. For an Indigenous moderniser who believes that 'liberal democracy, the rule of law, the Separation of Powers convention, separation of church and state, the free market economy and civil liberties' are 'the strongest values and institutions any nation can adopt' (p. 274), the political options are more limited than Mundine's admiration for these Asian models implies. He insists that the Aboriginal mindset ('that participating in the modern economy means turning your back on your culture') is 'wrong'. But with what political measures would Mundine correct it? Perhaps what Mundine really admires about these regimes is that they required people to work to survive. What he most dislikes in the Left is that, in his view, they perceive work as bad. 'Anyone who cares about social justice should want people to work,' he responds (p. 505). Work is a moral foundation for living-imperilled by advocates of welfare, he believes.

As well, as we noted above, Mundine promotes certain models of property right, arguing that 'communal' land tenure constrains Aboriginal development. In his memoir, he writes that his criticism of 'communal' tenure affronted three kinds of belief or opinion: a 'left' suspicion of 'private ownership and commerce' (p. 218); a belief that to legislate 'communal' tenures is to show respect to continuing Aboriginal custom; and a pragmatic fear that Aboriginal land 'would become like a Swiss cheese, peppered with holes of private title' (p. 220). He took 'a battering from the Aboriginal establishment' (p. 230). The Howard Government saw him as expressing 'Liberal values supporting individual rights and home ownership' (p. 229). In 2007, without consulting the Northern Territory Land Councils, it amended the Aboriginal Land Rights (Northern Territory) Act 1976 to facilitate leasehold on Aboriginal land. Mundine is confident that 'across the country' many Aboriginal landowners are now approaching land as an economic asset, as he has advocated (p. 229). 
One practitioner of the Northern Territory Aboriginal land rights system, Leon Terrill, has questioned Mundine's characterisation of the traditional owners' and residents' evolved property-owning practices as 'communal'. Terrill's work as a lawyer for the Central Land Council taught him that wherever people reside in small townships (former missions, settlements and pastoral homesteads) situated on larger tracts of Aboriginal land, they have evolved 'informal tenure arrangements' that 'provide individuals and organisation with relatively exclusive rights to particular land holdings and buildings'. ${ }^{50}$ Of course, this may not be 'modern' enough to satisfy Mundine's hope that Northern Territory Aboriginal people will adapt custom to capitalist, home-owning Australian norms.

\section{Counselling Howard, Abbott and Turnbull}

Mundine's willingness to become counsellor to Coalition governments is a corollary, in part, of his historical sense that non-Labor governments have been as helpful as Labor in their Indigenous policies (pp. 442-50). Laborites delude themselves that they are the natural party for Indigenous Australians, he argues; they are merely better than non-Labor at promoting what they have done (pp. 435-41). But his relationship with Abbott also reflects his view that both had 'grown in this area'. They no longer saw Indigenous Australians as 'sacred koalas' that 'needed to be helped ... We don't isolate indigenous affairs from the wider community. We see indigenous people as Australians, part of the Australian economy and part of the social fabric of Australia.'.51

Mundine's association with Liberal prime ministers has nonetheless brought occasional discomfort. He judges Howard 'stubborn' for refusing to apologise to the Stolen Generations; Howard was 'overwhelmed by defensiveness over Australian history' (p. 281). 'You can't ignore the anger and sorrow that any group of people feel about past wrongdoings that are relatively recent in history and where the flowon effects of it are still being felt. But you also can't be weighed down by it' (p. 283). He was pleased that Rudd apologised in February 2008. Mundine also questions whether the Howard Government should have suspended the Racial Discrimination Act 1975 when legislating the Northern Territory Intervention in 2007, as it implied that the policy was racist when, in his opinion, it was justifiable as securing the lives of Aboriginal women and children. Mundine also thinks that, 'in its implementation' (p. 293), the Intervention was arrogant and too much directed from Canberra. On what Howard thought of Mundine, his autobiography Lazarus Rising (2013) throws no light.

50 Leon Terrill, Beyond Communal and Individual Ownership: Indigenous Land Reform in Australia (Abingdon: Routledge, 2015), 131, doi.org/10.4324/9781315722474.

51 Robinson, 'Warren Mundine Ready to Assume Position of Power under Tony Abbott'. 
Advising Abbott was made easier for Mundine by the fact that under Rudd and Gillard (notwithstanding Rudd's 'socialistic' response to the Global Financial Crisis, pp. 326-28) the 'mindset' of the Australian Government had shifted from 'welfaredependency' to 'economic participation' (p. 325). It was unfortunate, Mundine concedes, that Abbott's promotion of the reformed mindset included saying, on one occasion, that remote Aboriginal people were making a regrettable 'life-style choice' (p. 395) and, on another occasion, that before British colonisation Australia had been 'unsettled' (p. 393). Abbott seemed, at times, clueless about how Aboriginal people understand themselves. Mundine did not form a close advisory relationship with Malcom Turnbull, finding that he was responsive to 'inner-city elites and the ABC lefties' (p. 414) but not genuinely interested in Indigenous affairs (p. 417); in Turnbull's memoir A Bigger Picture (2020), Mundine passes without mention.

Mundine nonetheless hails as the great legacy of the Abbott and Turnbull governments the Indigenous Entrepreneurs Capital Scheme-a government fund designed to reduce the risk of commercial lending to mature and established Indigenous businesses that cannot otherwise access finance. Labelling the scheme a 'game changer' ('I feel the tide has finally turned', p. 420), Mundine overstates the innovation that he has striven to bring about. There has been something like this scheme in Australian Government policy since 1968, when the Gorton Government passed the Aboriginal Enterprise (Assistance) Act 1968. The bipartisan aspiration that some Indigenous Australians will become entrepreneurs, like the long-standing willingness of governments of both kinds to lend for Indigenous home-ownership, has a lineage deeper than Mundine knows or at least admits. The position that he occupies in debates about 'Aboriginal development' is part of an established field of options; his views do not 'disrupt' an 'establishment' but join one side of a familiar debate that began in the late 1960s.

To understand how Mundine could experience himself as more novel than he is we need to consider three innovations within that field of debate that have intensified it without changing its polarities. First, there is more 'property' in play: the Native Title Act 1993, substantially amended in 1998, has hugely extended the Indigenous land and sea estate and has created and continues to create many new Indigenous property-owning corporations. More than ever, there is reason to ask what such property is good for and to expect a variety of answers-not least because the emergence of Green politics since the 1980s has complicated the moral choices of 'development' (pp. 422-32). Second, through innovations in official statistics, the state has developed its capacity to measure socioeconomic disparity between Indigenous Australia and Australians as a whole: the 'gap' that the nation is obliged to 'close'. Mundine rightly points to the biennial Closing the Gap report as propaganda (not his word but ours) for programs of Indigenous development such as he favours (pp. 309-10, 323, 383-87, 458-59). Third, the neglected needs of Indigenous women and children have been given more and more exposure since 
around 1990, creating a sense of crisis in Indigenous Australia that puts all extant policy settings on the defensive. Mundine gives ample attention to each of these three developments; they endow his voice with urgency because they give frequent and vivid exposure to the problems that concern him.

\section{Mundine in the constitutional recognition debate}

In November 2010, Julia Gillard commissioned an Expert Panel on Constitutional Recognition to come up with options for amending the Australian Constitution by referendum so that it 'recognised' Indigenous Australians. Within days of the Expert Panel's final meeting on 8 December 2011 and a month before it released its recommendations, Mundine was criticising its suggestions. We will go through them, one by one, describing Mundine's position in 2012.

First, the panel suggested getting rid of any mention of Commonwealth power to deal with people as if they were members of a 'race', such as Section 25 (allowing a state to exclude a 'race' from voting) and Section 51(xxvi) allowing the Commonwealth to pass laws about any 'race', with Aborigines and Torres Strait Islanders conventionally understood to be a 'race' or two 'races'. Before the report was released, Mundine was quoted as welcoming this recommendation..$^{52}$ "I'm not part of an "Aboriginal race" or a "black race",' he would later insist. 'I'm an Australian'. ${ }^{53}$

Second, because the 'race' power in Section 51 is the constitutional anchorage of such important statutes as the Native Title Act, it would be necessary to ensure the validity of certain Commonwealth laws by replacing Section 51 with a new power 'to make laws for the peace, order and good government of the Commonwealth with respect to Aboriginal and Torres Strait Islander peoples'. The words for describing this power would be part of a preamble to Section 51 that would recognise Aboriginal and Torres Strait Islander peoples as prior occupants of Australia with a continuing relationship to lands and waters and continuing culture; the preamble would also acknowledge these peoples' 'need' to 'secure ... advancement'. Before the Expert Panel released its report, Mundine was quoted as objecting that the proposed preamble would encourage High Court litigation on the issue of whether a law or policy would secure 'advancement' - a chance for lawyers to 'line their pockets for a 100 years', when the point of constitutional reform was to 'simplify the Constitution'. ${ }^{54} \mathrm{~A}$ few weeks later, Mundine again expressed 'very grave reservations' about this suggestion,

52 As paraphrased by Patricia Karvelas, 'Mundine to Fight New Race Power in Constitution', Australian, 19 December 2011; and see his later piece, Warren Mundine, 'Pitfall in Constitutional Change', Australian Financial Review, 25 January 2012.

53 Nyunggai Warren Mundine, 'Unfinished Business', in Davis and Langton, It's Our Country, 131.

54 Quoted by Karvelas, 'Mundine to Fight New Race Power in Constitution'. 
fearing that it would 'create scope for the courts to interpret government legislation in new ways ... I prefer laws to be made by elected parliamentarians, not members of the judiciary'. Litigation on constitutional validity could delay vital policies and programs, he added. ${ }^{55}$

Third, the panel recommended that the Constitution be amended to prohibit racial discrimination by any government in Australia - unless the discrimination was intended to overcome disadvantage, or to reduce the adverse impact of racial discrimination in the past, or to protect culture, language or heritage. In the words of Greg Craven, a constitutional lawyer, what the panel was proposing was 'a one-clause bill of rights'. ${ }^{56}$ Along similar lines, Mundine's commentary 'was vicious', Shireen Morris from the Melbourne Law School would later remark. She quoted Mundine as saying: "I'm concerned about the impact the advancement clause will have on the cultural practice of taking child brides in some aboriginal communities". ${ }^{57}$ It would empower courts to overturn decisions by elected governments. ${ }^{58}$ From the February 2012 meeting that she and Mundine had attended, Morris concluded that Abbott and Brandis 'wanted Parliament to retain its power to discriminate', rather than accept a general equality provision, and Mundine 'seemed to be nodding in agreement with Abbott and Brandis'. Cape York Aboriginal leader and Expert Panel member Noel Pearson, once debriefed, thought Mundine needed to 'harden up a bit'. Mundine seemed 'basically a minimalist', like Abbott. ${ }^{59}$

Fourth, while acknowledging English as Australia's 'national language', the Expert Panel wanted Australians to recognise that there remain other Aboriginal and Torres Strait Islander languages. We do not know Mundine's views about this recommendation, and it has been all but forgotten in the subsequent debate on constitutional recognition.

It quickly emerged that Mundine's views were shared by members of the Opposition. Shadow Attorney-General Brandis (Liberal, Queensland) urged Australians to heed Mundine's warning, describing him as 'one of Indigenous Australia's most intelligent and respected figures'; and he warned of the High Court's recent inclination to take 'a robust view of its powers to assess jurisdictional boundaries' ${ }^{60} \mathrm{~A}$ few days later, the Australian reported that Mundine had met with Abbott in order to formulate a combined attack on the second panel recommendation: the addition of words that require legislation to promote Indigenous 'advancement'. ${ }^{61}$ One of the unintended consequences that Mundine raised with Abbott was child brides: 'Some could argue

55 Warren Mundine, 'Pitfall in Constitutional Change', Australian Financial Review, 25 January 2012.

56 Quoted in Dan Harrison, 'Wording "a Gift to the No Campaign"', Sydney Morning Herald, 21 January 2012;

see also Greg Craven, 'Keep the Constitutional Change Simple', Australian Financial Review, 6 February 2012.

57 Morris, Radical Heart, 62.

58 Laura Tingle, 'Warning over Constitutional Guarantee', Australian Financial Review, 6 July 2015.

59 Morris, Radical Heart, 66, 69-70.

60 George Brandis, 'Modest Change Is Within Reach' Australian, 21 December 2011.

61 Patricia Karvelas, 'Mundine, Abbott Unite Over Race', Australian, 22 December 2011. 
it is about cultural rights, it could be used under the advancement clause. ${ }^{62}$ In the same issue of the Australian, Stuart Rintoul quoted Mundine as describing the panel's recommendations as the work of 'lawyers and intellectuals and academics' ${ }^{63}$ No praise there.

So, before the Expert Panel had formally submitted its recommendations, senior Opposition figures had initiated a line of criticism that they would make repeatedly with Mundine's support: that the proposed amendments to the Constitution would encourage litigation in the High Court to clarify which actions by government advanced Indigenous interests and which did not. To counter accusations that this position was racist, they could point out that 'one of Indigenous Australia's most intelligent and respected figures' shared their views. ${ }^{64}$ In addition, two prominent Aboriginal women, Sue Gordon and Bess Price, were reportedly critical of the panel's recommendations. ${ }^{65}$

One commentator whose views were close to the panel's acknowledged that Mundine and Brandis had pointed to a difficulty in the second recommendation: 'advancement', George Williams, Professor of Law at the University of New South Wales, agreed, was a 'vague and probably unhelpful' word to put into the proposed Section 51 preamble. He canvassed substitutes such as 'benefit', 'wellbeing' or 'welfare'. ${ }^{66}$ Clearly, these words would be no less open to interpretation by judges. The same problem arose in relation to the third of the panel's recommendations that would have made it necessary for the High Court (if the matter were litigated) to judge whether a government was committing 'racial discrimination' whenever a law or policy singled out Aborigines and Torres Strait Islanders for special treatment. The defining feature of the arguments by 'constitutional conservatives' against the panel's second and third proposals was their warning that Indigenous affairs laws and policies should not be any more vulnerable to the possibility of High Court litigation than they were under the existing Constitution. As Philip Ruddock, attorney-general in the last Howard Government explained, it would have been more difficult for the Howard Government to abolish ATSIC in 2004 and 2005 had the Constitution then included the proposed 'advancement' preamble and the 'anti-discrimination' Section. ${ }^{67}$ Abbott expressed a similar fear. ${ }^{68}$ This is precisely what commended the proposal to people on the other side of this debate.

62 Morris, Radical Heart, 62.

63 Stuart Rintoul, 'Race Power Opens Pandora's Box', Australian, 22 December 2011.

64 Gerard Henderson, 'No Vote at All Is Better than a Win for the NO', Australian, 24 January 2012; Patricia

Karvelas, 'Bob Carr Fears Misuse of Changed Constitution', Australian, 26 January 2012.

65 Christian Kerr, 'Libs Baulk on Referendum Support', Australian, 30 January 2012.

66 George Williams, 'Pathway to Referendum Success Is Now Clear', Sydney Morning Herald, 17 January 2012.

67 Stuart Rintoul and John Ferguson, 'Ruddock Warning on Constitutional Fallout', Australian, 26 December 2011.

68 Morris, Radical Heart, 65-66. 
The Liberal and National parties remained firm in the view that the legislature and executive should not be further constrained on 'Indigenous' matters by a reformed Constitution. When the Coalition parties took office on 18 September 2013, under Abbott, it was time for advocates of recognition to reconsider whether to continue to press for a referendum embodying the panel's second and third recommendations. Although Abbott led a government hostile to these recommendations, some kind of constitutional recognition was still possible, Pearson argued, not only because Abbott had long supported recognition, but also because Mundine was advising the government on how to increase the rate of employment of Indigenous Australians. Pearson's reasoning was that 'without demonstrable traction on the practical agenda, the symbolic reform [constitutional recognition] will face sceptical Australians, black and white'. ${ }^{69}$ Pearson, as a member of the Expert Panel, was hinting that it would be best to acknowledge that the constitutional conservatives had won the political debate on the 'advancement' (second) and 'anti-discrimination' (third) proposals and that it was time to reconsider the Expert Panel's 'rights' agenda of constitutional change.

Pearson had started a manoeuvre that, over the next three years, would recast the debate on constitutional recognition and alter Mundine's position within the debate. Pearson's Quarterly Essay, 'A Rightful Place' (2014), endorsed removing 'race' from Sections 25 and 51(xxvi) but urged respect for constitutional conservatives' fears of 'judicial activism' whose 'views' it was important to take 'on board'. ${ }^{70}$ In return, he asked constitutional conservatives to consider how to guarantee 'the indigenous voice in indigenous affairs' ${ }^{71}$ When writers in the Australian applauded Pearson's Quarterly Essay, one-Paul Kelly-singled out Pearson and Mundine as two admirably pragmatic Aboriginal leaders to whom Abbott must listen. ${ }^{72}$ However, as Mundine soon made clear, he would not support establishing an elected Indigenous Voice, insisting that Indigenous Australians are entitled only to the vote that every other voter gets at a general election. ${ }^{73}$

The idea of a national Voice was strongly affirmed in the 13 constitutional conventions (12 regional, 1 national) convened by the Referendum Council between October 2016 and May 2017. Pearson's proposal that there be a constitutional referendum to require the government to create a 'Voice to the Australian Parliament' was warmly endorsed by the 'Uluru Statement from the Heart' (May 2017) and

69 Noel Pearson, 'Written in the Stars: Time Is Right for Recognition', Australian, 27 January 2014.

70 Noel Pearson, 'A Rightful Place: Race Recognition and a More Complete Commonwealth', Quarterly Essay, no. 55 (2014): 52-53, 65.

71 Pearson, 'A Rightful Place', 66.

72 Paul Kelly, 'Passing Referendum Demands Urgent Action', Australian, 10 September 2014.

73 Sarah Martin and Simon King, 'Split Opens in Recognition Push', Australian, 14 April 2015; Sheridan, 'Mundine's Persuasive Blow Knocks Out Pearson's Case'. 
then by the Referendum Council in its Final Report (June 2017) ${ }^{74}$ Mundine endorsed the Turnbull Government's rejection, in October 2017, of this form of constitutional recognition.

\section{Mundine's approach to the Voice}

While opposed to a constitutionally entrenched Voice to Parliament, Mundine has not opposed to distinct Indigenous political institutions. Speaking to Sarah Maddison a decade earlier, he said: "We shouldn't be going to government and saying, "Hey, give us a national body." Why aren't we forming our own national body. Why don't we just do it??75 Mundine advocates the recognition of Indigenous nations. This means that he has engaged sympathetically with an issue raised by the Expert Panel in 2012: whether the Constitution's use of the word 'race' should continue to be understood as referring to Indigenous Australians. Mundine argues that 'race' is 'archaic and awkward' terminology that has long obscured that Indigenous Australia consists of many 'nations'. 'Removing the race power is a legitimate option. But history tells us any attempt to replace it with bans on racial discrimination or a requirement that laws benefit indigenous people will fail-and fuel a divisive debate. ${ }^{76} \mathrm{He}$ has said that he would support a constitutional change that acknowledges Australia's 'First Nations', though he does not suggest a form of words that would do this. ${ }^{77}$ Yet constitutional change may not be necessary to enable what Mundine calls 'treaties': the recognition of Indigenous nations as units of government. Legislated agreements with Indigenous bodies are possible under Australia's, the states' and the territories' existing constitutions. And, as Mundine acknowledges, the recognition of Indigenous nations will continue through the negotiation of land use agreements under the Native Title Act. 'Once registered, those agreements bind all native title holders in the agreement area, even those who didn't personally sign it [sic]. When signed with a government, they are, in a sense, a form of treaty' (p. 454). Under their existing constitutional powers, governmentsnational, state and territory—are able to sign such agreements and to encode them in legislation, if they wish.

For promoting 'treaties' in these terms, Mundine drew criticism from conservative commentators such as Andrew Bolt and Keith Windschuttle. ${ }^{78}$ However, Mundine claims that Abbott 'came round to my idea of treaties with Aboriginal first nations

\footnotetext{
74 Indeed, the Referendum Council has also set aside the Expert Panel's wish to remove 'race' from Sections 25 and 51. Referendum Council, Final Report of the Referendum Council (Canberra: Commonwealth of Australia, 2017).

75 Maddison, Black Politics, 40.

76 'Nationhood Has Nothing to Do with Race', Australian, 7 October 2014.

77 Mundine, 'Unfinished Business', 137.

78 Andrew Bolt, 'I Am, You Are ... All Indigenous Aussies', Daily Telegraph, 30 January 2014; Keith Windschuttle, The Break-Up of Australia: The Real Agenda behind Aboriginal Recognition (Balmain, NSW: Quadrant Books, 2016), 43, 142-43.
} 
(although to keep the peace with his conservative caucus he suggested that, if pursued, we should come up with a different name)' (pp. 405-6). Some state and territory governments have begun to negotiate acts of recognition with Indigenous Australians; such agreements would be legislated, not written into constitutions, and some refer to these prospective agreements as 'treaties'.

Treaties with local representative bodies ('nations') are Mundine's alternative to the single national Voice to Parliament. What is wrong with the Voice to Parliament, says Mundine, is that only each First Nation can speak for the Indigenous Australians in its region; he does not see a single national 'Voice' as capable of representing all Nations. "[T] he "debate that needs to happen" is about whether "people want an Aboriginal nation" or whether Aboriginal people remain "a nation of nations". 79 He would like the federal parliament to legislate for the creation of local representative bodies. Mundine's focus on the 'local' does not rule out the evolution of national Indigenous representation, however, for he concedes that:

Logic says that, once local bodies are created, they'll affiliate in representative State and Federal bodies. But, unlike a constitutionally created national body, any State or Federal body will be accountable to community through its connection to constituent 'peoples' or 'nations'. ${ }^{80}$

Mundine's thinking about multiple Indigenous nations illustrates that the relationship between two debates_-advocating treaties and advocating constitutional recognition-has not been straightforward. The Expert Panel in 2012 had tried to distinguish constitutional recognition from treaty negotiation; its report put treaty talk to one side and urged Australians to focus on options for constitutional recognition. However, in June 2016, Opposition leader Shorten brought up the relationship between the two when he answered a question from the floor in an ABC (Australian Broadcasting Corporation) TV Q $O A$ program; he acknowledged that a treaty or treaties could follow constitutional recognition. ${ }^{81}$ The Turnbull Government immediately warned that this made it harder to agree with Labor about the form that constitutional recognition might take. For those focused on finding a bipartisan referendum question, including Western Australia's Ken Wyatt-the first Aboriginal person to be elected to the House of Representatives, then the assistant minister for health and aged care-treaty talk was unwelcome. Langton

\footnotetext{
79 Maddison, Black Politics, 142.

80 Warren Mundine, Practical Recognition from the Mobs' Perspective: Enabling Our Mobs to Speak for Country, (Uphold \& Recognise, 2017), 10, static1.squarespace.com/static/57e8c98bbebafba4113308f7/t/59184bc71b10e3 f7ad227d72/1494764490065/Mundine-Practical_Recognition.pdf.

81 Josh Butler, 'Bill Shorten 'Up For' Treaty With Indigenous Australians', HuffPost, 14 June 2016, www.huffington post.com.au/2016/06/14/bill-shorten-up-for-treaty-with-indigenous-australians_a_21394810/.
} 
doubted that the ALP had formulated a clear policy on treaty and its relationship with constitutional recognition. ${ }^{82}$ The Australian editorialised that 'treaty talk can only derail constitutional recognition, ${ }^{83}$

As Indigenous persons responded to Shorten's intervention, the distinctive nature of Mundine's treaty proposal-reported along with those of others, including Patrick Dodson, looking forward to treaty negotiations-was at risk of being obscured. In June 2016, Mundine was reported as presenting treaty negotiations as an alternative to constitutional recognition: if Indigenous Australians could look forward to each 'nation' negotiating a treaty then they would not need to place so many of their hopes on changing the Constitution. The promise of treaty talks, he hoped, would convert many Indigenous people to the constitutional 'minimalist' position that he had been advocating since December 2011. ${ }^{84}$ However, in his 2017 essay Practical Recognition from the Mobs' Perspective he seems to be unsure whether the federal parliament has the power to legislate to recognise First Nations governments. $\mathrm{He}$ wonders whether a 'modest revision' of Section 51(xxvi) (by constitutional referendum) would be required to authorise the federal government to pass laws to establish First Nations governments. ${ }^{85}$

Pressure to hold a referendum to give the Australian Government a constitutional obligation to legislate a Voice to Parliament, as urged by the Uluru Statement, has not abated; it has grown. However, how the Voice should represent multiple local/ regional voices, and whether the Voice(s) should be 'to the Parliament of Australia' or 'to government' at all three levels are now issues for debate. In 2018, a Joint Select Committee on Constitutional Recognition relating to Aboriginal and Torres Strait Islander Peoples (chaired by Julian Leeser, Liberal, Berowra, and senator Patrick Dodson, Labor, Western Australia) received many submissions arguing that constitutional change should take the form of special measures to ensure Indigenous contributions to policymaking. These submissions sketched a variety of designs for such a Voice. Mundine did not make a submission, but the committee's final report in November 2018 took note of his May 2017 paper Practical Recognition from the Mobs' Perspective and his proposal that 'recognition' should be about recognising First Nations as interlocutors of governments. For Mundine, 'Only traditional owners can speak for their country. Specifically: Bundjalung speak for Bundjalung country. Yuin speak for Yuin country. Yolngu speak for Yolngu country.' In his view,

82 Fleur Anderson, 'Bipartisanship Rocked over Indigenous Treaty', Australian Financial Review, 15 June 2016; Tom Mcllroy and Michael Koziol, 'PM Faces Renewed Push for a Treaty', Sydney Morning Herald, 15 June 2016; Stephen Fitzpatrick, 'Langton Questions Opposition Backing of Indigenous Push', Australian, 15 June 2016.

83 'Treaty Talk Can Only Derail Constitutional Recognition', Australian, 16 June 2016.

84 Stephen Fitzpatrick, 'Treaty Can Be Pressure Valve, Says Mundine', Australian, 16 June 2016.

85 Mundine, Practical Recognition from the Mobs' Perspective, 9. 
'a national voice can't speak for any country' ${ }^{86}$ Indeed, many submissions argued for the local and regional representation of all Indigenous nations. Mundine's view that the Voices be regional and that they should address all levels of government and not just the national parliament seems to have wider currency among Indigenous Australians.

In 2015, as we have noted, Marcia Langton warned not to expect an Indigenous consensus on constitutional recognition, and indeed a variety of Indigenous positions about the design and status of the Indigenous Voice has emerged. Mundine's regional approach to Indigenous representation is, more than ever, a part of the discussion of the Indigenous Voice. Throughout 2020, three committees appointed by the government began to 'co-design' the Voice; resulting in an Interim Report, co-authored by Langton and Tom Calma, and released by Minister for Indigenous Affairs Wyatt on 9 January 2021. Mundine's Mobs' Perspective is not mentioned, but the report's proposal that there be 25 to 35 Local and Regional Voices, recognised by all three levels of government, mediating 'community' (including traditional owners') views to the National Voice and to all three levels of government, is broadly consistent with what Mundine has been advocating. Wyatt's three committees are now considering submissions about how many Local and Regional Voices there should be. In line with the Morrison Government's opposition to entrenching the Voice(s) in the Constitution, none of the committees will be able to present the Voice(s) as a form of constitutional recognition. From 2011 to 2014, Mundine opposed constitutional recognition that would have put certain Indigenous rights into the Constitution. Subsequently, he came to favour 'recognising first Nations voices in the Constitution', though after the Uluru Statement he is said to have 'wavered'. ${ }^{87}$ Pearson's and others' skilful promotion of the Voice(s) option has brought attention to Mundine's championing of the multiple Indigenous nations as the political expression of Indigenous agency. The constitutional recognition debate has evolved so that its permitted agenda and excluded options have come to resemble Mundine's preferences.

86 Warren Mundine, 'Why a National Voice to Parliament Is Doomed to Fail', Australian Financial Review, 10 September 2019, www.afr.com/politics/federal/why-a-national-voice-to-parliament-is-doomed-to-fail-20190909p52pg7.

87 Morris, Radical Heart, 189. 
This text is taken from Australian Journal of Biography and History: No. 5, 2021, published 2021 by ANU Press, The Australian National University, Canberra, Australia.

doi.org/10.22459/AJBH.05.2021.10 